\title{
Combat Sports (1934), by Captain Bádenas-Padilla: analysis of an outstanding handbook in the modern history of martial arts and combat sports in Spain
}

\author{
Carlos GUTIÉRREZ-GARCÍA*1, Joseph R. SVINTH², Juan Carlos MARTÍN ${ }^{*}$ \& Eugenio IZQUIERDO1 \\ ${ }^{1}$ Universidad de León (Spain) \\ ${ }^{2}$ Electronic Journals of Martial Arts and Sciences (United States)
}

\section{Introduction}

In 1934, Captain José Bádenas-Padilla (1902-1936), a professor of the Escuela Central de Gimnasia de Toledo [Toledo Central School of Gymnastics], published Deportes de Combate [Combat Sports]. This pioneering and comprehensive two-volume (336 pages plus illustrations) handbook focused on some of the combat sports known in those days, to include boxing, wrestling, fencing and jiujitsu. This study is aimed at analyzing this work within the historical context in which it was written, taking into account both the situation of martial arts and combat sports (MA\&CS) and the development of physical education and sport sciences (PE\&SC) in Spain at that time

\section{Methodology}

Descriptive and interpretative analyses were performed on Bádenas-Padilla's original work. For the descriptive analysis, we synthesized the contents of the book and the author's main ideas. For the interpretative analysis, we used primary sources (historical press and books), secondary sources (studies on the evolution of MA\&CS and PE\&SC in Spain), and tertiary sources (mainly the reference works by Pérez-Gutiérrez, Gutiérrez-García, \& Álvarez del Palacio, 2013; Pérez-Gutiérrez \& Gutiérrez-García, 2008; and Green \& Svinth, 2010), which helped us to put in context this piece into its socio-cultural context.

\section{Results and discussion}

Bádenas-Padilla's purpose in writing this book was to show the utility and practical development of combat sports, both for the army and civilians, as means of comprehensive education, active entertainment, and defense (defense of the country, of others, and self-defense). It is divided into the following sections: (1) Preface; (2) Boxing, including international ("English") and French boxing (savate); (3) Wrestling, including Greco-Roman and freestyle wrestling; (4) Fencing, including stick fencing; (5) Jiu-jitsu; (6) Teaching issues; (7) Appendix 1: The human body from the point of view of jiu-jitsu; and (8) Kuatsu, or the Japanese art to revive someone who is unconscious. Jiu-jitsu (sections 5, $7 \&$ 8) is quantitatively the main content of the book (153 of 336 pages; 45.5\%), reflecting the preference of the author for jiu-jitsu due to its characteristics of simplicity, effectiveness, scientific nature, and promoter of whole development (physical, moral and intellectual).This is not strange, as jiu-jitsu (especially in the form of Kodokan judo) was popularized in Western countries since the late nineteenth century as a complex physical education system in which gymnastic, hygienic, and sport elements were merged (Green \& Svinth, 2010). Other combat sports, such as international ("English") boxing or wrestling lacked, in the 
perspective of the author, some of the character-building qualities of jiu-jitsu and even had the negative social connotations associated with professionalized sports (Gutiérrez-García, 2004; Sánchez-García, 2009).

Therefore, Bádenas-Padilla's point of view is that of a PE\&SC educator. In his day, although sports were progressively growing in popularity, gymnastics, especially Swedish military gymnastics, had the strongest influence in the PE\&SC in Spain (Vinuesa\&Vinuesa, 1995). Aware of the traditional importance of combat sports for the army, but recognizing the educational potential of sports in general, Bádenas-Padilla analyzes the cited combat sports both under a "sportive" and "utilitarian" perspective (including technique, tactics, training, or teaching) and under the "gymnastic" perspective, in which aspects such as hygiene, harmonious and symmetrical body development, safety, control of violence, and accessibility for all were also taken into account.

\section{Conclusion}

Combat Sports was an outstanding effort in analyzing and promoting MA\&CS in the Spanish army under the rationale, technical, and scientific scope of PE\&SC. Nevertheless, the purpose of Combat Sports was not achieved due to the Spanish Civil War (1936-1939), during which Captain BádenasPadilla died and the Toledo Central School of Gymnastics was practically destroyed (GutiérrezGarcía, 2004).

\section{References}

Badenas-Padilla, J. (1934). Deportes de Combate (2 vols.). Toledo: Establecimiento tipográfico de Rafael G.-Menor.

Gutiérrez-García, C. (2004). Introducción y desarrollo del judo en España (de principios del siglo XX a 1965): el proceso de implantación de un método educativo y de combate importado de Japón. León: Universidad de León.

Pérez-Gutiérrez, M., \& Gutiérrez-García, C. (2008). 100 años de artes marciales: repertorio bibliográfico de monografías publicadas en España (1906-2006). León: Universidad de León.

Pérez-Gutiérrez, M., Gutiérrez-García, C., \& Álvarez del Palacio, E. (2013). Annotated bibliography about Asian martial arts monographs published in Spain. Revista de Artes Marciales Asiáticas, $8(1), 21-450$.

Green, T. A., \& Svinth, J. R. (2010).Martial Arts of the World: An Encyclopedia of History and Innovation (2 vols.). Santa Bárbara, CA: ABC-CLIO.

Sánchez-García, R. (2009). Boxeo y proceso de civilización en la sociedad española. Apunts. Educación Física y Deportes, 96, 5-13.

Vinuesa, M., \& Vinuesa, I. (1995). La Escuela de Gimnasia de Toledo. Toledo: Diputación Provincial de Toledo.

Key words: Martial arts; combat sports; jujutsu; Spanish Army; sport history; bibliography. 